
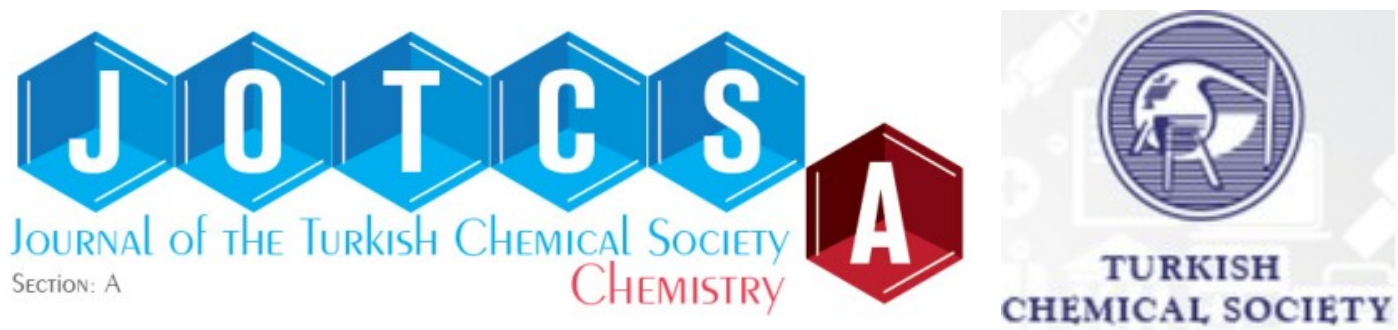

\title{
Anticancer Activities of Even-Numbered Monoketo Eicosanoic Acid Anilides and Semicarbazones
}

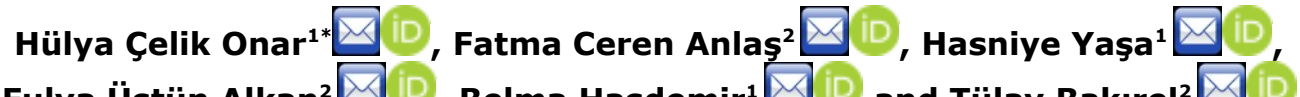 \\ Fulya Üstün Alkan ${ }^{2} D$, Belma Hasdemir ${ }^{1} D$ and Tülay Bakırel ${ }^{2}$ D
}

\begin{abstract}
${ }^{1}$ Istanbul University-Cerrahpaşa Engineering Faculty, Chemistry Department, Organic Chemistry Division, Avcilar/İstanbul/Turkey.

${ }^{2}$ Istanbul University-Cerrahpaşa Veterinary Faculty, Pharmacology and Toxicology Department, Avcilar/İstanbul/Turkey.
\end{abstract}

Abstract : This work was carried out on the cytotoxic activity of semicarbazone and anilide derivatives of ketoeicosanoic acids on canine mammary tumor cell line (CMT-U27). Five semicarbazone compounds (15) and five anilide compounds (6-10) were used in this study. 8-Semicarbazone eicosanoic acid (3) was shown to be cytotoxic. In contrast, 10-keto eicosanoic acid anilide (9) has been shown to be less cytotoxic towards CMT-U27 cell line.

Keywords: Anilide, Semicarbazone, Fatty Acid,Canine mammary tumor, MTT Assay.

Submitted: June 28, 2019. Accepted: September 24, 2019.

Cite this: Çelik Onar H, Anlaş F, Yaşa H, Üstün Alkan F, Hasdemir B, Bakırel T. Anticancer Activities of Even-Numbered Monoketo Eicosanoic Acid Anilides and Semicarbazones. JOTCSA. 2019;6(3):429-32.

DOI: https://doi.org/10.18596/jotcsa.583845.

${ }^{*}$ Corresponding author. E-mail: hcelikonar@gmail.com.

\section{INTRODUCTION}

In recent years, pharmaceutical industry has been focused on the development of new innovative drugs for cancer therapy, due to cancer represents an important health problem at a global level. Many natural and synthetic compounds are in charge of affecting selectively specific organs and tissues within a biological system. Particularly heterocyclic compounds are being studied as anticancer reagents. Among such compounds, Schiff bases are important functional groups in terms of biological activities as antimicrobial (1-3), anti-inflammatory $(4,5)$, analgesic $(6,7)$, and pesticidal agents $(8,9)$.

Keto-fatty acids are stable compounds. High molecular weight keto-fatty acids constitute the structure of plant waxes. There are many literature reports on the biological activity of fatty acids. For example, antibacterial effects of $\mathrm{C}_{12}-\mathrm{C}_{18}$ saturated and unsaturated fatty acids have been observed (10). As another one, it has been suggested that surfactants prepared from fatty acids have a skin irritation-reducing effect. They show good biodegradability and low toxicity, so they are defined as environmentally friendly (11). Amides and anilides are also important in pharmaceutical, agrochemical industries, and are used as protecting groups in organic synthesis $(12,13)$. It has been proved that some of the fatty acid amides and anilides synthesized have good activity against gram-positive bacteria (14). The anticancer activities of vanillin semicarbazone have been reported against Ehrlich Ascites Carcinoma (EAC) (15).

In this study, anilide and semicarbazone derivatives of (4-12) monoketo $C_{20}$ fatty acids were examined as anti-cancer agent on canine mammary tumor cell line (CMT-U27) and the effect of the position of the keto group were also, 
too. Canine mammary tumors (CMTs) are most frequent neoplasia in female dogs, as well as considered as a suitable model for human breast cancer.

\section{MATERIAL AND METHODS}

\section{(4-12) Monoketo eicosanoic acid anilides} and semicarbazones synthesis

In previous work, 4-, 6-, 8-,10- and 12-keto $\mathrm{C}_{20}$ esters were synthesized by Blaise reaction with high purity by Çelik and Özeriş. These esters were hydrolyzed to the corresponding carboxylic acids. Then semicarbazone and anilide derivatives of keto acids were obtained (16).

\section{Cell line and reagents}

The canine mammary carcinoma cell line CMTU27 was kindly donated by Dr. Eva Hellmén from Uppsala University, Sweden. Cell line was maintained in Dulbecco's modified Eagles Medium (DMEM-F12) (Invitrogen, CA) supplemented with $1 \%(\mathrm{v} / \mathrm{v})$ L-glutamine (Gibco, USA), 10\% (v/v) heat-inactivated fetal bovine serum (Invitrogen, CA) and $100 \mathrm{U} / \mathrm{mL}$ penicillin and $100 \mu \mathrm{g} / \mathrm{mL}$ streptomycin (Gibco, Grand Island, NY, USA) at $37^{\circ} \mathrm{C}$ in a humidified atmosphere of $5 \% \mathrm{CO}_{2}$. The cells were cultured at $37^{\circ} \mathrm{C}$ in a humidified atmosphere with $5 \% \quad \mathrm{CO}_{2}$. Cells were subcultured as they reached $80-90 \%$ confluence and adherent cells were detached by incubation with Trypsin/EDTA solution. Cell number was determined using a $0.2 \%$ trypan blue dye with the Cedex XS cell counter system (Innovatis, Roche, Germany). Anilide and semicarbazone derivatives of $\mathrm{C}_{20}$ keto fatty acids were dissolved in dimethyl sulfoxide and then further diluted in culture media. Doxorubicin was purchased from Sigma-Aldrich (St Louis, MO, USA) and dissolved in culture media.

\section{MTT assay}

Cell viability was assessed using a commercial cell proliferation MTT [3-(4,5-dimethylthiazol-2yl)-2,5-diphenyltrazolium bromide] kit (Roche Applied Science, Germany) according to the manufacturer's instructions. Briefly, cells were seeded at a density of $1 \times 10^{4}$ cells/well in 96-well plates (Jet Biofil, Canada) and then allowed to settle and attach overnight in culture media and incubated at $37{ }^{\circ} \mathrm{C}$ in a humidified atmosphere of $5 \% \mathrm{CO}_{2}$ for $24 \mathrm{~h}$ and then treated with varying concentrations of anilide and semicarbazone derivatives of $\mathrm{C}_{20}$ keto fatty acids (3.25 - 100 $\mu \mathrm{M})$ and doxorubicin $(0.2-8 \mu \mathrm{M})$ for $72 \mathrm{~h}$. At the end of incubation period $10 \mu \mathrm{L}$ of MTT solution [5 $\mathrm{mg} / \mathrm{mL}$ in phosphate buffered saline (PBS)] were added to each well. The plates were incubated for $4 \mathrm{~h}$ in a humidified atmosphere at $37^{\circ} \mathrm{C}$ with $5 \%$ CO2. The purple water- insoluble formazan salt was then dissolved with $10 \%$ SDS in $0.01 \mathrm{M} \mathrm{HCl}$ and the plates were incubated overnight in a cell culture incubator. The optical densities of the wells were measured at $595 \mathrm{~nm}$ using a MultiMode microplate reader (FilterMax F5, Molecular Devices, USA). The effect of each compound on growth inhibition was assessed as percent cell viability where vehicle (DMSO)-treated cells were taken as $100 \%$ viable. The mean of triplicate experiments for each dose was used to calculate the concentration of compounds required for $50 \%$ inhibition of cell viability $\left(\mathrm{IC}_{50}\right)$ as determined using the Biosoft CalcuSyn software (Biosoft, UK).

\section{RESULTS AND DISCUSSION}

This work was carried out on the cytotoxic activity of semicarbazone and anilide derivatives of keto eicosanoic acids on canine mammary tumor cell line (CMT-U27). Five semicarbazone compounds (1-5) and five anilide compounds (610) were used in this study (Scheme 1).

$$
\underset{\mathrm{CH}_{3}\left(\mathrm{CH}_{2}\right) \mathrm{nC}\left(\mathrm{CH}_{2}\right) \mathrm{mCOOH}}{\mathrm{NNHCONH}}
$$

1-5

$$
\mathrm{CH}_{3}\left(\mathrm{CH}_{2}\right) \mathrm{nCO}\left(\mathrm{CH}_{2}\right) \mathrm{mCONHC}_{6} \mathrm{H}_{5}
$$

\section{6-10}

$\begin{array}{ll}\mathbf{1}(\mathrm{n}: 15, \mathrm{~m}: 2) & \mathbf{6}(\mathrm{n}: 15, \mathrm{~m}: 2) \\ \mathbf{2}(\mathrm{n}: 13, \mathrm{~m}: 4) & \mathbf{7}(\mathrm{n}: 13, \mathrm{~m}: 4) \\ \mathbf{3}(\mathrm{n}: 11, \mathrm{~m}: 6) & \mathbf{8}(\mathrm{n}: 11, \mathrm{~m}: 6) \\ \mathbf{4}(\mathrm{n}: 9, \mathrm{~m}: 8) & \mathbf{9}(\mathrm{n}: 9, \mathrm{~m}: 8) \\ \mathbf{5}(\mathrm{n}: 7, \mathrm{~m}: 10) & \mathbf{1 0}(\mathrm{n}: 7, \mathrm{~m}: 10)\end{array}$

Scheme 1. Semicarbazone and anilide derivatives of keto eicosanoic acids.

The cytotoxicity was determined using 3-(4,5dimethylthiazol-2-yl)-2,5-diphenyltetrazolium bromide (MTT) assay. The half maximal inhibitory 
concentrations $\left(\mathrm{IC}_{50}\right)$ were calculated by using Calcusyn software.

At the end of the 72 hour treatment, only compounds, 8-semicarbazone eicosanoic acid (3) and 10-keto eicosanoic acid anilide (9) inhibited cell growth towards CMT-U27 cell line. The other compounds did not show appreciable activity in the experiments performed (Table 1). Among these compounds, 8-semicarbazone eicosanoic acid (3) and 10-keto eicosanoic acid anilide (9) displayed effective cytotoxic potential against CMT-U27 and IC $_{50}$ concentrations were recorded at $1.952 \mu \mathrm{M}$ and $54.01 \mu \mathrm{M}$, respectively. The $\mathrm{IC}_{50}$ of doxorubicin as a positive control (chemotherapeutic agent) was founded as 0.8 $\mu \mathrm{M}$.

Table 1. Cytotoxic activity of keto eicosanoic acid anilides and semicarbazone eicosanoic acids

\begin{tabular}{|c|c|c|c|c|c|c|c|}
\hline \multirow[t]{2}{*}{ Compound } & \multicolumn{7}{|c|}{ Cytotoxicity (\%) } \\
\hline & $100 \mu \mathrm{M}$ & $75 \mu \mathrm{M}$ & $50 \mu \mathrm{M}$ & $25 \mu \mathrm{M}$ & $12.5 \mu \mathrm{M}$ & $6.25 \mu \mathrm{M}$ & $3.125 \mu \mathrm{M}$ \\
\hline 1 & - & - & - & - & - & - & - \\
\hline 2 & - & - & - & - & - & - & - \\
\hline 3 & 65.77 & 75.26 & 70.32 & 57.95 & 60.32 & 60.75 & 54.27 \\
\hline 4 & - & - & - & - & - & - & - \\
\hline 5 & - & - & - & - & - & - & - \\
\hline 6 & - & - & - & - & - & - & - \\
\hline 7 & - & - & - & - & - & - & - \\
\hline 8 & - & - & - & - & - & - & - \\
\hline 9 & 61.72 & 56.45 & 53.45 & 31.39 & 27.43 & 22.79 & 26.45 \\
\hline 10 & - & - & - & - & - & - & - \\
\hline
\end{tabular}

3: 8-Semicarbazone eicosanoic acid 9: 10-Keto eicosanoic acid anilide

Cytotoxic activity was not detected in 4-,6-,10-,12-semicarbazone eicosanoic acids and 4-, 6-, 8-, 12-keto eicosanoic acid anilides and, when the keto group is evaluated in terms of its location, it has been found that the keto functional group has a better cytotoxic activity if it is in the middle of the chain. Anilide and semicarbazone containing a keto group at the beginning or at the end of the chain did not show cytotoxic activity against the CMTU 27 tumor.

8-Semicarbazone eicosanoic acid (3) was shown to be cytotoxic. In contrast, 10 -keto eicosanoic acid anilide (9) has been shown to be less cytotoxic towards CMT-U27 cell line.

Our results indicate that 8-semicarbazone eicosanoic acid (3) may benefit as a novel chemopreventive compounds for anticancer therapy.

\section{REFERENCES}

1. Venkatesh P. Synthesis, characterization and antimicrobial activity of various schiff bases complexes of $\mathrm{Zn}(\mathrm{II})$ and $\mathrm{Cu}(\mathrm{II})$ ions. Asian J Pharm. Hea. Sci. 2011; 1: 8-11.

2. Hussein MA, Omar RH, Farghaly $H S$. Design, synthesis, structure elucidation and biochemical evaluation of some schiff's base derivatives bearing pyrazolo [3,4-D] pyrimidine-4-ones. Int. ]. Acad Res. 2011; 3 (2): 454-462.
3. Nair R, Shah A, Baluja S, Chanda S. Synthesis and antibacterial activity of some schiff base complexes. J. Serb. Chem. Soc. 2006; 71: 733-44.

4. Sathe BS, Jaychandran E, Jagtap VA, Sreenivasa GM. Synthesis characterization and anti-inflammatory evaluation of new fluorobenzothiazole schiff's bases. Int. J. Pharm. Res. Dev. 2011; 3: 164-69.

5. Pandey A, Dewangan D, Verma S, Mishra A, Dubey RD. Synthesis of schiff bases of 2-amino-5-aryl-1, 3, 4thiadiazole and its analgesic, antiinflammatory, antibacterial and antitubercular activity. Int. J. Chem. Tech. Res. 2011; 3: 178-84.

6. Fahmy $\mathrm{HH}$, El-Eraky W. Synthesis and evaluation of analgesic and antiinflammatory activities of O- substituted salicylamides. Arch. Pharm. Res. 2001; 24: 171-179.

7. Chinnasamy RP, Sundararagan R, Govindaraj S. Synthesis, characterization and analgesic activity of novel Schiff base isatin derivatives. J. Adv. Pharm. Technol. Res. 2010; 1: 342-347.

8. Ali MM, Jesmin M, Salam SMA, Khanam JA, Islam MF, Islam MN. Pesticidal activities of some schiff bases derived from benzoin, salicylaldehde, 


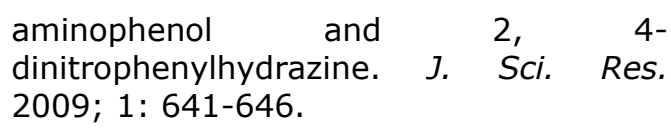

9. Jesmin M, Ali MM, Islam MN. Pesticidal Activity of some Schiff Base Complexes Derived from some Divalent Metal Acetates, Glycine and Salicylaldehyde. J. Sci. Found. 2008; 6: 49-56.

10. Jon JK, Swieczkowski DM, Anthony JC, Truant JP. Fatty Acids and Derivatives as Antimicrobial Agents. Antimicrob. Agents Chemother. 1972; 2 (1): 23-28.

11. Maag $H$. Fatty acid derivatives: Important surfactants for household, cosmetic and industrial purposes. J. Am. Oil Chem. Soc. 1984; 61: 259-267.

12. Pasha MA, Nanjundaswamy HM. Reductive fission of azoarenes to aminoarenes by aluminium/hydrazine hydrate. J. Chem. Res. 1984; 750-752.

13. Hartley D, Kidd H. The Agrochemicals Hand Book, 2nd ed.; Royal Society of Chemistry: Nottingham, 1987; p 215.

14. Maurer EW, Smith FD. Fatty acid amides and anilides, syntheses and antimicrobial properties. J. Am. Oil Chem. Soc. 1980; 57: 98-103.

15. Shaikh MMA, Azad MAK, Jesmin M, Ahsan S, Rahman MM, Kraham JA, Islam MN, Shahria SMS. In vivo anticancer activity of vanillin semicarbazone. Asian Pac. J. Trop. Biomed. 2012; 438-442.

16. Çelik $H$, Özeriş $S$. Synthesis of Even Numbered of (2-12) Monohydroxy Eicosanoic Acid Isomers. Chim. Acta Turc. 1996; 24: 23-27. 